\title{
WINTER PROTECTION OF TREE FERNS AT THE ROYAL BOTANIC GARDEN EDINBURGH
}

\author{
Andrew Ensoll ${ }^{1}$, Louise Galloway ${ }^{2}$ \& Alastair Wardlaw ${ }^{3}$
}

Ten plants of six species of tree fern were trialled for frost hardiness during the winter of 2005/06 when they were planted outdoors in the ground of an interior courtyard at the Royal Botanic Garden Edinburgh. The species were Culcita macrocarpa, Cyathea dealbata, Cyathea dregei, Cyathea smithii, Dicksonia antarctica and Thyrsopteris elegans. An additional specimen of $C$. dregei was planted in the main garden. The apex region of each tree fern was fitted with an electric thermometer probe to record weekly minimum and maximum temperatures. These were compared with the air temperatures of the courtyard. For thermal insulation, the trunks and crowns of the three Cyathea species were encased in straw. The prostrate rhizomes of C. macrocarpa and $T$. elegans were covered respectively with leaf litter, straw and a polystyrene tile. As comparators, three trunked specimens of $D$. antarctica were given no winter wrapping, since previous experience had shown it to be unnecessary. All ten plants survived the winter of 2005/06 which was colder than average, and put out new growth the following spring. Fronds of D. antarctica and C. macrocarpa stayed green; the fronds of the other species were withered by the coldest exposures when the air temperature reached $4.7^{\circ} \mathrm{C}$.

Compared with the main botanic garden, the courtyard provided a relatively mild microclimate. It was on average $2.5^{\circ} \mathrm{C}$ warmer than the air temperature measured in the screen of the main garden weather station, and $7.7^{\circ} \mathrm{C}$ warmer than the 'grass' temperature in the main garden, which went down to $-13^{\circ} \mathrm{C}$ at its lowest. All tree fern apices registered sub-zero temperatures, the range in different plants being from -0.3 to $-3.4^{\circ} \mathrm{C}$. The apex regions did not get as cold as the surrounding air temperature, which ranged between 0.5 and $2.3^{\circ} \mathrm{C}$. The three $D$. antarctica (without added insulation) had minimum apical temperatures in the same range as the species that were wrapped for the winter. The insulation effect in the apex regions was also shown by the weekly maximum temperatures, which on average were lower than those of the courtyard air maxima.

In conclusion, the combination of the locally favourable microclimate of the courtyard, plus appropriate trunk and crown insulation provided for some species, allowed the planting outdoors, of tree ferns normally grown in Edinburgh under heated glass.

\section{INTRODUCTION}

Most of the tree ferns at the Royal Botanic Garden Edinburgh (RBGE) are kept in a heated glasshouse, except for those that have been maintained outdoors (some for over

\footnotetext{
${ }^{1}$ Andrew Ensoll is a Senior Horticulturist at the Royal Botanic Garden Edinburgh where he is responsible for the fern collection.

Address: 20A Inverleith Row, Edinburgh EH3 5LR.

Email: a.ensoll@ rbge.org.uk

${ }^{2}$ Louise Galloway is Indoor Department Supervisor at Royal Botanic Garden Edinburgh

Address: as above.

Email: 1.galloway@rbge.org.uk

${ }^{3}$ Alastair Wardlaw is holder of the NCCPG National Collection of British Ferns, and is a past President of the British Pteridological Society.

Address: 92 Drymen Road, Bearsden, Glasgow G61 2SY.

Email: a.wardlaw@tiscali.co.uk
} 
100 years) at RBGE's Logan Botanic Garden on the Galloway Peninsula of South-West Scotland. At Edinburgh in recent years, a few tree ferns have been trialled for growth outdoors, both in the ground of an interior courtyard at the RBGE Inverleith Row building and in the main garden. The courtyard is completely surrounded by two-storey buildings which deliver some warmth and wind protection. However, it is open to the sky and therefore at risk of radiation frosts on clear nights. The tree fern site in the main garden is a bed of cobble stones with a southerly exposure and located a few metres from the main glasshouse.

In 1998, the interior courtyard at the Inverleith Row building was planted with five trunked specimens of Dicksonia antarctica, which previously had been grown under heated glass. These tree ferns subsequently thrived in the new location, with little or no frost damage to their fronds, despite not being wrapped during winter. Five years later, in the winter of 2003/04, we decided to investigate the minimum temperatures of both the air in the courtyard and also deep within the apical cleft at the top of the trunk of each tree fern. These tree fern apex and courtyard air temperatures were then compared with the weekly minima ('screen' and 'grass' temperatures) at the weather station in the main garden.

As we reported previously (Wardlaw, Galloway \& Ensoll, 2005), the lowest apical cleft temperature of a $D$. antarctica during the winter of $2003 / 04$ was $-0.8^{\circ} \mathrm{C}$, which the plant survived without withering of the fronds or other damage. The lowest air temperature in the courtyard was $-3.2^{\circ} \mathrm{C}$, highlighting both the natural insulating effect of the apical cleft and the colder temperature of the air around the fronds. The courtyard demonstrably provided a mild environment compared with the main garden, where the minimum air temperature that winter was $-7.1{ }^{\circ} \mathrm{C}$, and the minimum 'grass' temperature was $-11.2^{\circ} \mathrm{C}$. Weather station records showed that the winter of $2003 / 04$, as judged by monthly minimum temperatures, was close to the average of the previous 19 years.

The present study extends the range of tree fern species, by reporting apical and air temperatures of the additional species added to the courtyard collection during the summer of 2005. Thus during the winter of 2005/06 we were able to record the apex and air temperatures of Culcita macrocarpa, Cyathea dealbata, Cyathea dregei (2 specimens), Cyathea smithii (2 specimens) and Thyrsopteris elegans. As comparators, three of the Dicksonia antarctica from the 2003/04 investigation were included. The $D$. antarctica, as in the previous study, were not wrapped over winter. However, to protect against possible frost damage, winter wrapping was provided for the other tree ferns, as described below.

\section{MATERIALS \& METHODS}

Courtyard. The RBGE building complex at 20A Inverleith Row contains an interior courtyard (not normally accessible to the public) of dimensions $6.5 \times 20.3 \mathrm{~m}$. It is open to the sky and bounded on its four sides by two-story, harled masonry walls with 


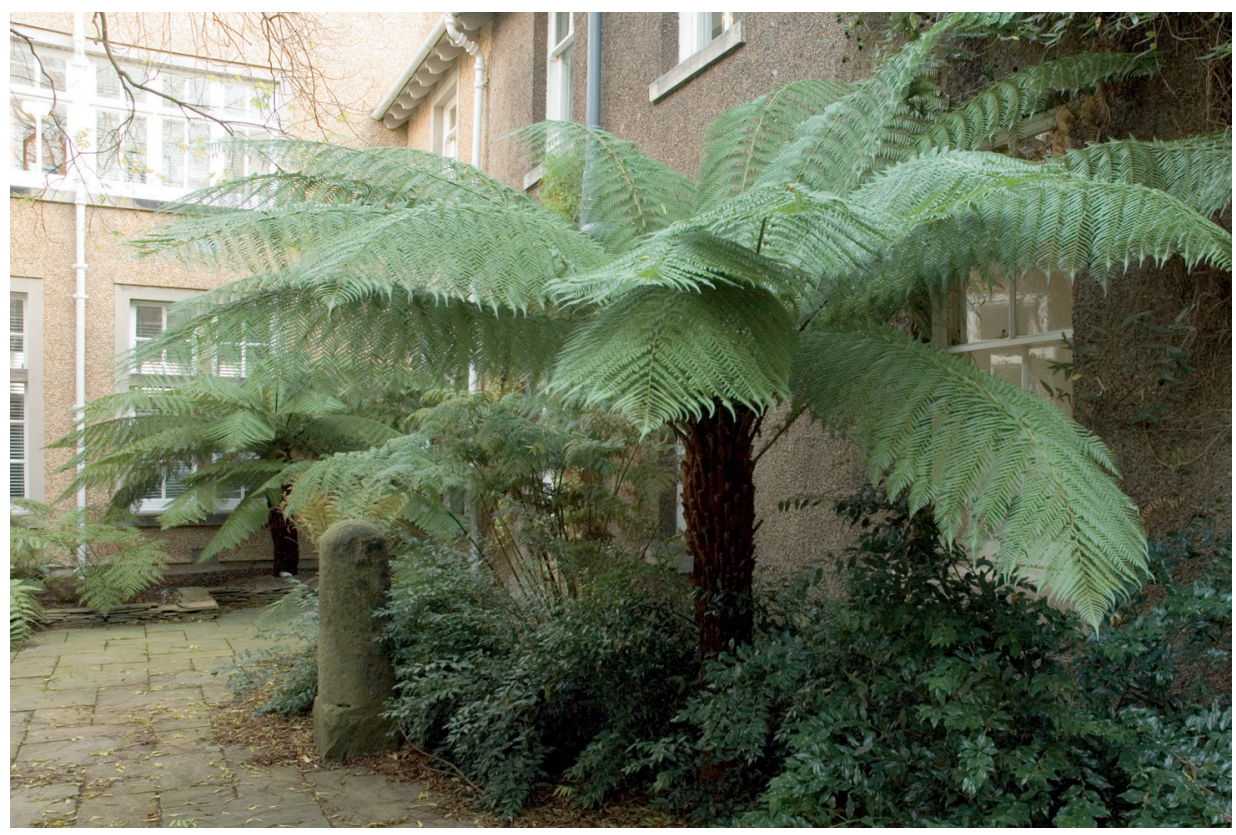

Plate 1 Interior courtyard at the RBGE building on Inverleith Row in early winter 2005/06, showing the 2-storey harled masonry walls with numerous windows. Left distance: bed with Thyrsopteris elegans, Cyathea dealbata and (rightwards) Dicksonia antarctica (140cm trunk). Centre, immediately right of pillar: Culcita macrocarpa. Directly behind the pillar, and only just visible, projecting above, is a Cyathea smithii (45cm trunk). Right off-centre: Dicksonia antarctica (185cm trunk). Right foreground Sarcococca confusa. Left overhead: bare branches of Pistacia chinensis. Photo: Lynsey Muir.

numerous windows, not double-glazed (Plate 1). Winter heat-transfer from the building to the courtyard may therefore be considerable. The periphery of the courtyard has beds planted with tree ferns, some other ferns and shrubs (Sarcococca confusa, Sarcococca hookeriana var. digyna and Pistacia chinensis). The central area is paved. The planting beds contained good quality garden loam and were fertilized sparingly with chicken pellet manure. Irrigation of the plants was largely dependent on natural rainfall, with additional hand watering during dry spells.

Tree ferns. Five trunked specimens of Dicksonia antarctica were dug out from the public display fernery in a heated glasshouse and planted in the courtyard in 1998. Their original provenance was New South Wales. In the summer of 2005, additional tree ferns, also raised under heated glass, were added: one plant of Cyathea dealbata, sourced from the North Island of New Zealand, and with a short trunk of $20 \mathrm{~cm}$; two specimens of Cyathea smithii, with trunks of 45 and $65 \mathrm{~cm}$, from the South Island of New Zealand; and one Cyathea dregei grown from spores collected on the Drakensberg Mountains of South Africa, with a $55 \mathrm{~cm}$ trunk. From the same source, a $C$. dregei with $25 \mathrm{~cm}$ trunk was planted in the cobble bed outside the glasshouse in the main garden. Although normally 
lacking erect trunks, Culcita macrocarpa and Thyrsopteris elegans were included as 'tree ferns' in this study, since they are so treated in the monograph on tree ferns by Large \& Braggins (2004). The C. macrocarpa had been grown from spores collected on the Island of Madeira. The T. elegans, an endemic species of the Juan Fernandez Islands, was a division from a plant that had been growing for many years in the Kibble Palace at Glasgow Botanic Gardens.

Winter protection. The three $D$. antarctica in the present study received no winter protection, other than that provided by their location in the courtyard, and the small quantity of Pistacia leaves falling into the crowns. The other trunked tree ferns $(C$. dealbata, $C$. dregei and $C$. smithii) had their trunk and crown encased in straw which was secured with horticultural netting and thermal screening material, as shown in Plates 2 and 3. The prostrate rhizome of C. macrocarpa (Plate 3) was covered with several centimetres of withered Pistacia leaves. The apex region of the T. elegans (Plate 3) was covered with straw which lets in some moisture but is breathable. A polystyrene tile was tied down over it, with the primary purpose of shedding water.

Temperature measurement. Each tree fern was fitted with an individual electric thermometer, Model No. BTH-112, from ATP Instrumentation Ltd, Tournament Way, Ivanhoe Industrial Estate, Ashby de la Zouch, Leicestershire LE65 2UU. The temperature sensors had a claimed resolution of $0.1^{\circ} \mathrm{C}$ and accuracy of $\pm 1^{\circ} \mathrm{C}$. Before use in the study, the thermometers were tested for equivalence by placing in a closed box whose temperature was raised slowly from $0^{\circ} \mathrm{C}$ to $20^{\circ} \mathrm{C}$. All instruments gave the same readings to within $0.5^{\circ} \mathrm{C}$. For use in the survey, each instrument had its sensor, at the end of a flexible lead, inserted as deeply as possible, but without damaging fern tissue, into the apical cleft at the crown of the tree fern trunk. With C. macrocarpa and T. elegans which lack clefts at the apex, the probe was placed closely adjacent to the apex region. To prevent dislodgement, the sensor lead of each probe was tied to a stipe base for the duration of observations. The plastic case of each thermometer containing another sensor to measure air temperature, plus the electronics and display screen, was mounted on a cane approx $65 \mathrm{~cm}$ above ground level and as far as possible from the fern. Rain protection of each thermometer case was provided by a plastic cover, perforated to allow circulation of air while excluding water. Weekly readings of minimum and maximum temperatures at each tree fern apex and case were taken over the 5.5-month period from 23 November 2005 until 26 April 2006. The thermometers were re-set after recording the readings each week.

These apex and courtyard temperatures were compared with the 'screen' and 'grass' temperatures in the official records from the RBGE weather station located in the main botanic garden. Official records of winter temperatures back to 1984-85 were also obtained in order to compare the winter of 2005/06 with the 21 previous winters.

Statistical analysis of temperatures and production of graphics were done with Minitab Statistics Software (Wardlaw, 2000) and Microsoft Excel. 

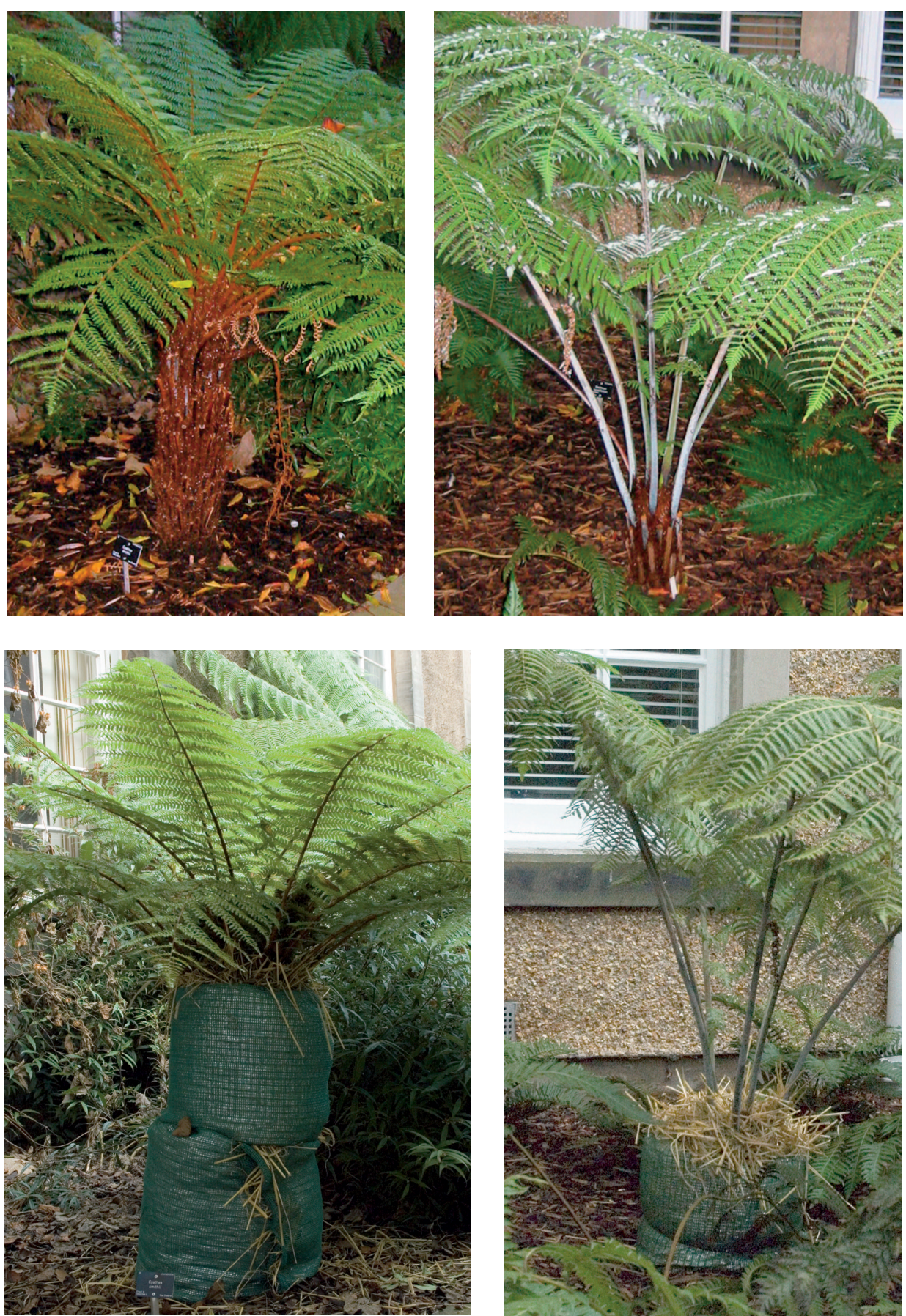

Plate 2 Before (Top Photo: Alaistair Wardlaw) and after (Bottom Photo: Lynsey Muir) wrapping tree ferns. Left: Cyathea smithii (65cm trunk). Right: Cyathea dealbata (20cm trunk). 

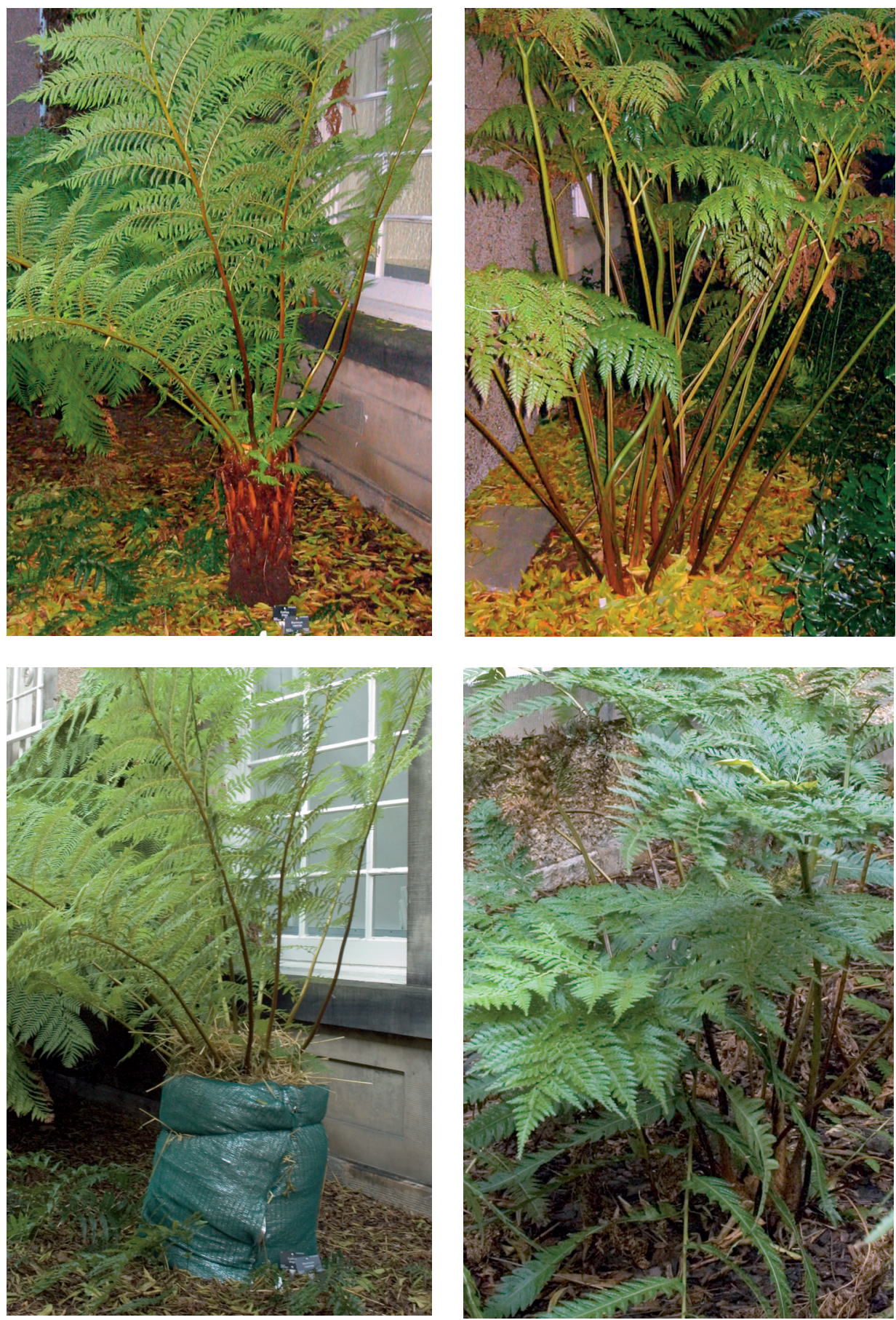

Plate 3 Left: Cyathea dregei (55cm trunk) before (Top Photo: Alaistair Wardlaw) and after (Bottom Photo: Lynsey Muir) wrapping. Right, top: Culcita macrocarpa, with leaf-litter heaped on the prostrate rhizome Photo: Alaistair Wardlaw. Right, bottom: Thyrsopteris elegans, before adding insulation (straw + polystyrene tile) to cover the apical region. Photo: Alastair Wardlaw. 


\section{RESULTS}

Tree fern and courtyard air temperatures. All ten of the tree ferns in the present study survived the winter and put out new fronds the following spring. Weekly readings of minimum and maximum temperatures in one of the tree fern apical clefts, and in the nearby air, are presented as a representative sample in Fig. 1. These data were obtained for the tallest $(1.85 \mathrm{~m})$ specimen of Dicksonia antarctica (Plate 1). The solid blue line shows that the apical temperatures dipped slightly below $0^{\circ} \mathrm{C}$ on 3 occasions during the winter. The dashed blue line, representing the nearby air temperature in the courtyard, is mostly lower than the solid line, indicating that the tree fern apical cleft had an insulating effect against these cold exposures. The insulating effect was also demonstrated by the weekly maximum temperatures, plotted in red. These present a more closely parallel movement of apex and air temperatures, with the insulating effect revealed by the tree fern apex not warming up as much as the surrounding air.

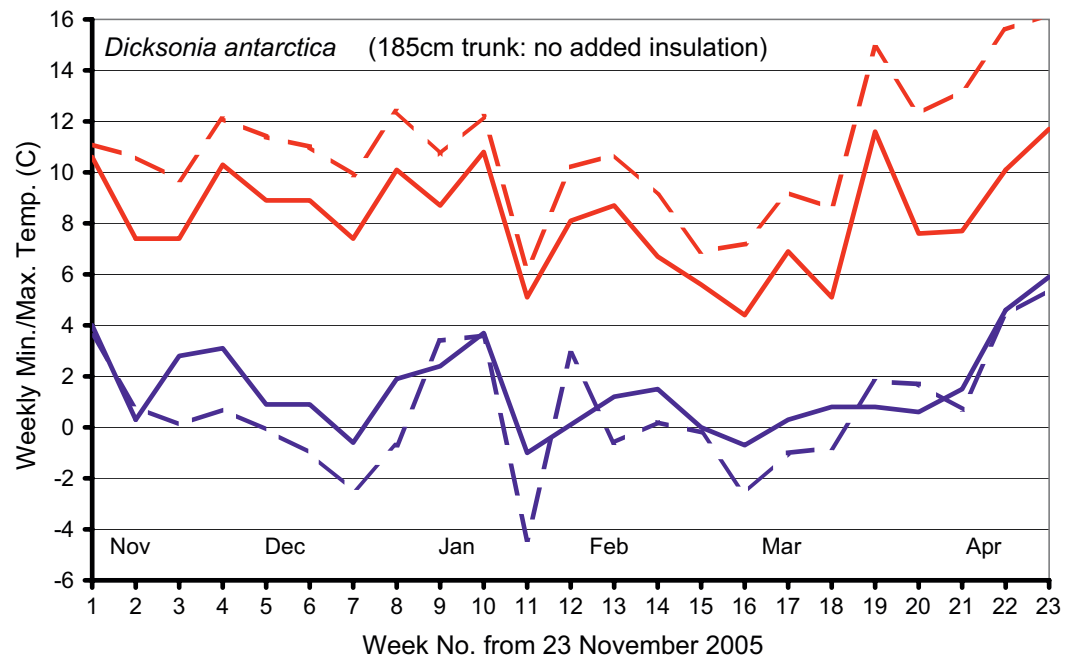

Fig. 1 Weekly temperatures of Dicksonia antarctica (Plate 1) with $185 \mathrm{~cm}$ trunk, in the RBGE courtyard during the winter of 2005/06. Maximum temperatures: red; minimum temperatures: blue. Apical cleft: solid lines; air temperature: dashed lines.

Whereas the above tree fern, and the two other $D$. antarctica were not given added insulation, the two tree ferns in Fig. 2 were both wrapped for winter. The trunk and crown of the $65 \mathrm{~cm}$ Cyathea smithii was encased in straw (Plate 2). The prostrate rhizome of Culcita macrocarpa in the lower part of Fig. 2 was covered with leaf litter (Plate 3). These two plants gave temperature results with the same general pattern as those from D. antarctica, that is that the apical temperatures dipped below $0{ }^{\circ} \mathrm{C}$ during the coldest periods. The thermal insulating effects were also revealed by the fact that 
the apex minima tended to be less cold that the air minima, and the apex maxima were below those of the air maxima.
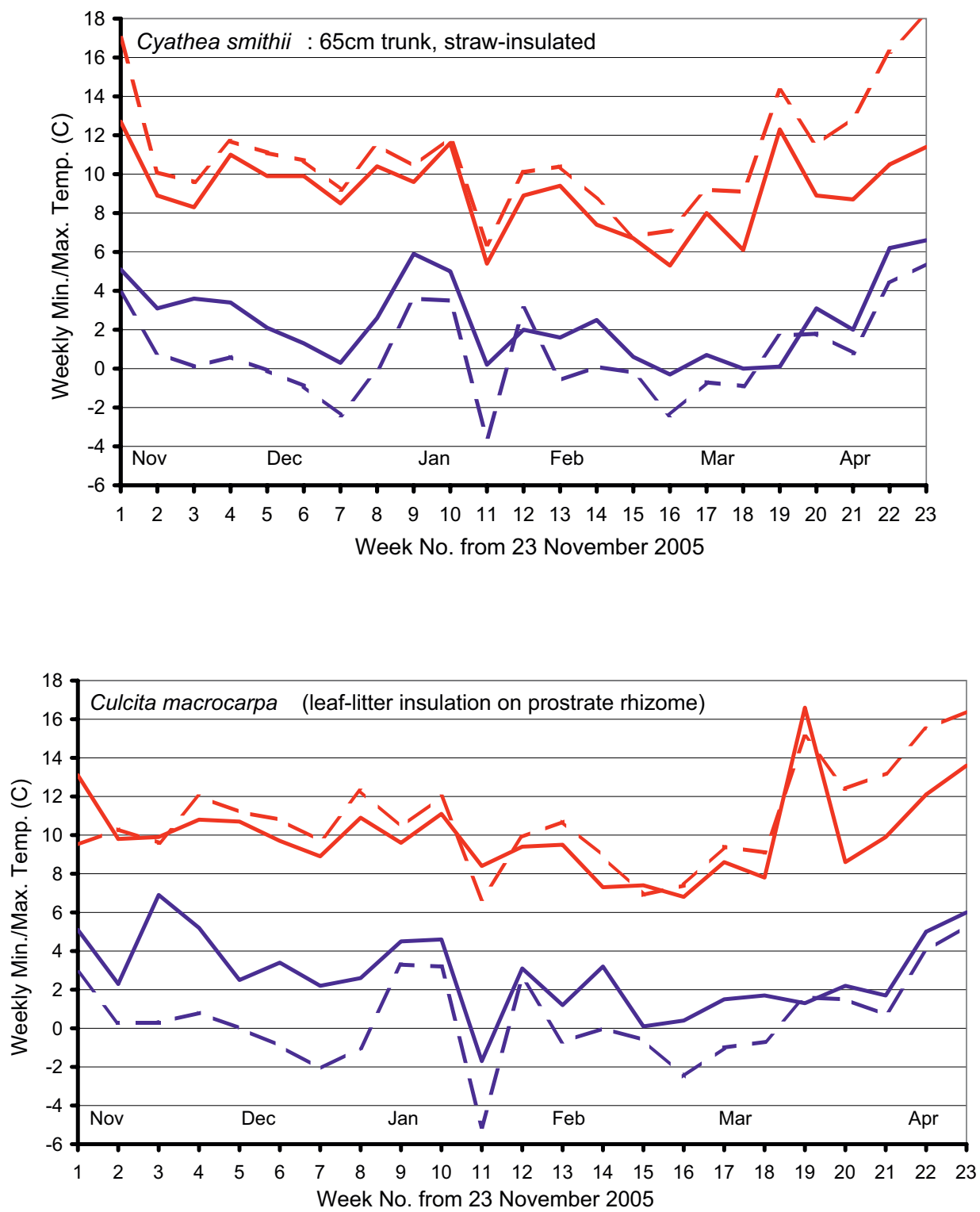

Fig. 2 Weekly temperatures of Cyathea smithii (Plate 2) with $65 \mathrm{~cm}$ trunk, insulated with straw, and Culcita macrocarpa (Plate 3), with prostrate rhizome insulated with leaf litter. Maximum temperatures: red; minimum temperatures, blue: Apical regions: solid lines; air temperature: dashed lines. 
The other seven tree ferns, whose detailed temperature profiles are not presented, gave diagrams of the same general type as those illustrated in Figs. 1 and 2. Table 1 summarises the minimum apex temperatures, which in all ten plants were below $0^{\circ} \mathrm{C}$, the lowest being -2.9 and $-3.4^{\circ} \mathrm{C}$. The table also gives the dates when the apex minima were recorded, and the effect of the freezing air temperatures on the fronds. Withering of fronds occurred with $C$. dregei, C. smithii and T. elegans, but not to any appreciable extent with $D$. antarctica or $C$. macrocarpa.

The insulating effect of the tree fern apices was explored by further analysis (Table $2)$. Each of the 23 values of average $(\mathrm{N}=9)$ minimum weekly air temperatures in the courtyard was subtracted from the corresponding 23 weekly readings of the apex minimum for each tree fern. These temperature differences are summarised as the mean and SEM in the third column of Table 2, and show the extent to which the ferns are insulated against the cold with a range from $0.85^{\circ} \mathrm{C}$ to $3.56^{\circ} \mathrm{C}$, and a mean of $1.54^{\circ} \mathrm{C}$. The difference in temperature between the air and the apices showed that the insulating effect was nearly double that of the air temperature. This is shown by the air apex differences in the temperature maxima (4th column of Table 2) than with the temperature minima. The range with the maxima was from $1.93{ }^{\circ} \mathrm{C}$ to $6.17^{\circ} \mathrm{C}$, with a mean of $4.1^{\circ} \mathrm{C}$. Thus although from a horticultural standpoint the insulating effect for lowering the temperature is of most interest, it may also be useful to make the calculations with the temperature maxima, since the revealed insulating effect may be numerically larger.

\begin{tabular}{|c|c|c|c|c|}
\hline $\begin{array}{l}\text { Tree-fern species } \\
\text { (trunk height: cm) }\end{array}$ & $\begin{array}{c}\text { Installed } \\
\text { insulation }\end{array}$ & $\begin{array}{c}\text { Apex area } \\
\text { minimum }\left({ }^{\circ} \mathrm{C}\right)\end{array}$ & $\begin{array}{c}\text { Date } \\
2005 / 06\end{array}$ & $\begin{array}{l}\text { Effect of freezing } \\
\text { temperatures } \\
\text { on fronds }\end{array}$ \\
\hline Dicksonia antarctica (105) & none & -0.8 & 8 Mar & minimal \\
\hline Dicksonia antarctica (140) & none & -0.6 & $1 \mathrm{Feb}$ & minimal \\
\hline Dicksonia antarctica (185) & none & -1.0 & $1 \mathrm{Feb}$ & minimal \\
\hline Culcita macrocarpa & leaf litter ${ }^{\mathrm{a}, \mathrm{b}}$ & -1.7 & $1 \mathrm{Feb}$ & none noted \\
\hline Thyrsopteris elegans & straw+polystyrene ${ }^{\mathrm{b}}$ & -2.9 & $1 \mathrm{Feb}$ & withered \\
\hline Cyathea dealbata & straw $^{c}$ & -1.4 & $1 \mathrm{Feb}$ & withered \\
\hline Cyathea dregei (25) & straw & -1.0 & $15 \mathrm{Mar}$ & withered $^{\mathrm{d}}$ \\
\hline Cyathea dregei (55) & straw $^{\mathrm{a}}$ & -3.4 & $1 \mathrm{Feb}$ & withered \\
\hline Cyathea smithii (45) & straw & -0.9 & $1 \mathrm{Mar}$ & withered \\
\hline Cyathea smithii (65) & straw $^{\mathrm{c}}$ & -0.3 & $8 \mathrm{Mar}$ & withered \\
\hline
\end{tabular}

${ }^{\mathrm{a} A s}$ illustrated in Plate3.

${ }^{\mathrm{b}}$ Covering the prostrate rhizome.

${ }^{\mathrm{c}}$ As illustrated in Plate 2.

${ }^{\mathrm{d}}$ The fronds were cut off after withering and before the main wrapping of the crown for the winter.

Table 1. Tree ferns during the winter of 2005/06: Method of insulation, apical minimum temperatures and date, and the effect of freezing temperatures on the fronds. Except for Cyathea dregei (25) in the main garden, all were planted in the courtyard. 


\begin{tabular}{|c|c|c|c|}
\hline \multirow[t]{2}{*}{$\begin{array}{l}\text { Tree-fern species } \\
\text { (trunk height: cm) }\end{array}$} & \multirow[t]{2}{*}{$\begin{array}{l}\text { Installed } \\
\text { insulation }\end{array}$} & \multicolumn{2}{|c|}{$\begin{array}{l}\text { Temperature difference }\left({ }^{\circ} \mathrm{C}\right) \text { : apex minus air } \\
\text { (Mean of } 23 \text { weekly observations } \pm \text { SEM) }\end{array}$} \\
\hline & & Minima & Maxima \\
\hline Dicksonia antarctica (105) & none & $1.94 \pm 0.18$ & $-2.69 \pm 0.31$ \\
\hline Dicksonia antarctica (140) & none & $1.38 \pm 0.27$ & $-4.23 \pm 0.43$ \\
\hline Dicksonia antarctica (185) & none & $0.85 \pm 0.31$ & $-2.68 \pm 0.28$ \\
\hline Culcita macrocarpa & leaf litter ${ }^{\mathrm{a}, \mathrm{b}}$ & $2.31 \pm 0.34$ & $-0.82 \pm 0.35$ \\
\hline Thyrsopteris elegans & straw+polystyrene $\mathrm{e}^{\mathrm{b}}$ & $0.88 \pm 0.44$ & $-6.17 \pm 1.44$ \\
\hline Cyathea dealbata (20) & straw $^{c}$ & $1.46 \pm 0.34$ & $-2.90 \pm 0.47$ \\
\hline Cyathea dregei (25) & straw & $3.56 \pm 0.35$ & $-3.89 \pm 0.44$ \\
\hline Cyathea dregei (55) & straw $^{\mathrm{a}}$ & $0.38 \pm 0.20$ & $-4.10 \pm 1.14$ \\
\hline Cyathea smithii (45) & straw & $0.92 \pm 0.31$ & $-2.94 \pm 0.44$ \\
\hline Cyathea smithii (65) & straw $^{c}$ & $1.73 \pm 0.26$ & $-1.93 \pm 0.37$ \\
\hline
\end{tabular}

${ }^{\mathrm{a}}$ As illustrated in Plate 3.

${ }^{\mathrm{b}}$ Covering the prostrate rhizome.

${ }^{\mathrm{c} A s}$ illustrated in Plate 2.

Table 2. Effects of insulation at tree fern apices, as measured by the differences between their weekly $\mathrm{min} / \mathrm{max}$ temperatures with those of the ambient air. All tree ferns were planted in the courtyard, except for Cyathea dregei (25) which was in the main Garden, and whose temperatures were compared with those in the weather station 'screen'.

Air temperatures. The coldest period in the winter of 2005/06 was during the week ending 1 February, when the air in the courtyard dipped to nearly $-5^{\circ} \mathrm{C}$. In that week the 9 thermometers in the courtyard registered minimum air temperatures $\left({ }^{\circ} \mathrm{C}\right)$ of: -3.6 , $-4.9,-4.7,-5.1,-5.0,-4.4,-4.8,-5.1,-4.4$, an average of $-4.7^{\circ} \mathrm{C}$. The corresponding minimum 'screen' temperature in the main garden was $-6.9^{\circ} \mathrm{C}$ and the minimum 'grass' temperature was $-13.0^{\circ} \mathrm{C}$. The second and third coldest weeks ended on 4th January and 8th March, when the average minimum air temperatures in the courtyard were -2.1 and $-2.4^{\circ} \mathrm{C}$ respectively. The corresponding 'screen' and 'grass' temperatures were respectively $-4.2,-4.9^{\circ} \mathrm{C}$ and $-9.0,-13.0^{\circ} \mathrm{C}$.

Fig. 3 compares the weekly minimum and maximum temperatures for the air in the courtyard with the corresponding 'screen' temperatures at the weather station. The dashed blue line for the air temperature in the courtyard is clearly above the solid blue line for the garden 'screen', the average difference ( \pm SEM) being $2.9 \pm 0.3^{\circ} \mathrm{C}$. The minimum 'grass' temperatures are also plotted in Fig. 3. Note how the green line of the 'grass' minima runs appreciably lower than either of the blue lines for the air temperatures. The average difference between weekly courtyard air and 'grass' minima ( \pm SEM) was $8.4 \pm 0.5^{\circ} \mathrm{C}$.

However, while on cold nights the courtyard stayed warmer than the main garden, 


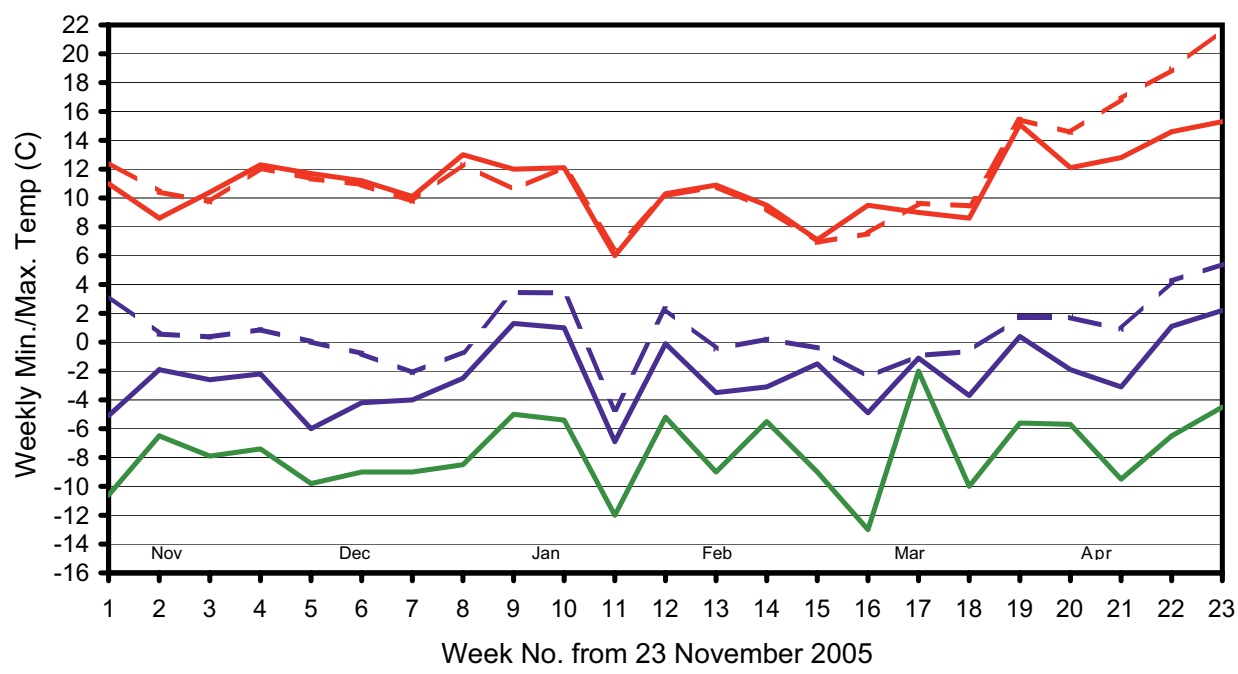

Fig. 3 Comparison of weekly maximum and minimum temperatures in the courtyard and at the weather station during the winter of 2005/06. Red: maxima; blue: minima; green: 'grass' minimum; solid lines: weather station 'screen'; dashed lines: courtyard.

it did not seem to reach higher maximum temperatures (Fig. 3). An exception was in the April data where the courtyard and 'screen' readings diverged, as plotted at the right side of Fig. 3. This is likely to be a spurious effect of sunlight falling directly on the thermometer cases which contain the air temperature sensors. Such heating of the thermometer case was also noted with the thermometer attached to the $C$. dregei in the main garden. During April 2006, the weekly maxima diverged markedly upwards from those of the 'screen', illustrating the difference between 'sun' and 'shade' measurements of air temperature.

Another measure of the relatively mild environment of the courtyard was the number of weeks out of 23, between 23 November, 2005 and 26 April, 2006, when the weekly minimum fell below freezing point. There were 9 such weeks in the courtyard, compared with 17 at the 'screen'. The 'grass' temperatures had a minimum below $0{ }^{\circ} \mathrm{C}$ in every one of the 23 weeks monitored.

Relative severity of the 2005/06 winter. The 2005/06 winter was compared for severity with earlier years, taking the monthly minimum 'screen' temperatures from RBGE weather station records back to 1984/85. Fig. 4 presents these 22 years of monthly 'screen' minima, highlighting 2005/06 with red squares, while using blue squares for the 2003/04 winter studied previously by Wardlaw et al. (2005). Although November, December and February of 2005/06 were average to mild for the last two decades, January, March and April were more severe than average. Based on mean monthly 'screen' minima for November through to April, the 2005/06 winter was overall the sixth 


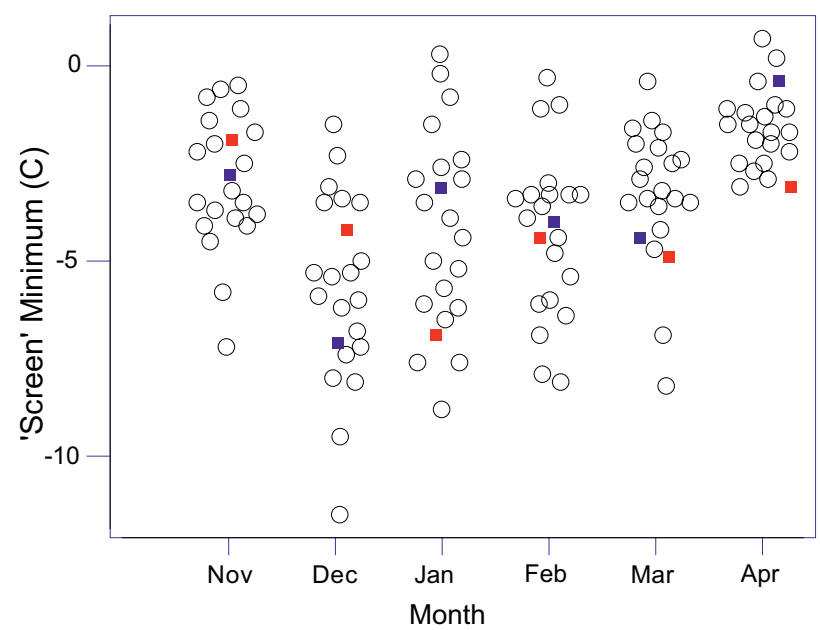

Fig. 4 Monthly minimum 'screen' temperatures at the RBGE weather station. Solid red squares: winter of 2005/06 (current study); solid blue squares; winter of 2003/04 (previous study of Wardlaw et al., 2005); open black circles: all other winters between 1984/85 and 2005/06.

coldest within the 22 year period, while the 2003/04 winter was eleventh coldest and, as such, close to the average.

\section{DISCUSSION}

Our observations agree broadly with the information in the European Garden Flora (Walters et al., 1986) where a hardiness rating of 'H5-G1' is given to Dicksonia antarctica, Cyathea dealbata and Culcita macrocarpa. H5 is defined as 'hardy in favourable areas; withstands 0 to $-5^{\circ} \mathrm{C}$.' The definition of $\mathrm{G} 1$ is 'needs a cool glasshouse even in south Europe.' There is no mention of Cyathea dregei or Cyathea smithii in this monograph, which perhaps reflects the recent availability of these species in British and European horticulture. Large \& Braggins (2004) state that $C$. dregei 'may resist slight frosts', while C. smithii 'do best in cooler areas and will withstand frost provided they are given well drained humus with plentiful moisture and shelter from wind'. Our observations add quantitative information by recording actual temperature minima within apical clefts, and in the surrounding air, during freezing conditions. It is possible that Thyrsopteris elegans may be hardier than stated in the European Garden Flora, which categorises it as 'G2', 'needs a heated glasshouse even in south Europe.' Our T. elegans stayed green through air temperatures down to about $-1^{\circ} \mathrm{C}$ but had its fronds withered by the $-4.7^{\circ} \mathrm{C}$ air minimum in late January. On the other hand, its apical area apparently withstood exposure down to $-2.9^{\circ} \mathrm{C}$. Nevertheless the plant survived, as did several other plants of this species nearby in the same bed. Indeed one of these T. elegans in an alcove of the building, but still open to the sky, had fronds that stayed green throughout the winter of 2005/06. 
Our decision not to wrap the three $D$. antarctica was based on the experience of previous winters, which suggested that it was not necessary, since the fronds mainly stayed green in the winters back to 1999 and the plants produced new growth each spring. The Royal Horticultural Society (1989) placed D. antarctica in the 'half-hardy' category, defined as 'can withstand temperatures down to $0^{\circ} \mathrm{C}$ '. This, in our experience, understates the hardiness slightly, since the fronds withstood down to nearly $-5^{\circ} \mathrm{C}$ in the courtyard, with minimal damage, while the apical areas went down to $-1^{\circ} \mathrm{C}$. We noted, however, that the fronds which emerge in late summer of $D$. antarctica were partially withered by the lowest winter temperatures. Whether temperatures below $-1^{\circ} \mathrm{C}$ in the apex might have been lethal is a matter of speculation, as we have no direct temperature measurements on plants in environments colder than the RBGE courtyard. D. antarctica has survived colder winter temperatures regularly at Logan Botanic Gardens where an extreme minimum of $-11.5^{\circ} \mathrm{C}$ ('screen') has been recorded. Winters at Logan normally cause some withering of the fronds of this species and may also kill some of the specimens with short trunks. Further published information on the hardiness of this and other tree fern species was given in our previous paper (Wardlaw et al., 2005).

The courtyard in the present study evidently provided a relatively mild microenvironment. Thus during the coldest week of the winter, in late January 2006, the courtyard minimum was $-4.7^{\circ} \mathrm{C}$, which was over $2^{\circ} \mathrm{C}$ warmer than the air temperature of $-6.9^{\circ} \mathrm{C}$ recorded as the 'screen' minimum in the main garden. Exposure to this $-4.7^{\circ} \mathrm{C}$ air temperature in the courtyard withered the fronds of the three Cyathea species and $T$. elegans. However it had little detrimental effect on the fronds of Culcita macrocarpa or of D. antarctica, except on the second flush of late summer fronds of the latter. All ten tree ferns put out plentiful new growth the following spring, showing that they had survived. It may be noted that the winter minimum of $-4.7^{\circ} \mathrm{C}$ in the courtyard during $2005 / 06$ was somewhat colder than the $-3.2^{\circ} \mathrm{C}$ minimum recorded in the winter of 2003/04 in which the temperatures experienced were closer to average levels.

There are several directions in which these trials could be extended. For example, it would be useful to monitor apex and air temperatures of tree ferns routinely for several years, in the hope of recording more extreme temperatures and different effects from those that we have observed so far. The list of species could also be enlarged, as could the trialling of plants of different sizes, different periods of establishment and different methods of winter wrapping, including none. It would also be interesting to determine how low the apex temperatures go in the natural habitats of these mainly Southern Hemisphere exotics. Another factor, probably relevant to winter hardiness, may be the summer maximum temperatures, with their potential maturing effect on plant tissues. As regards winter protection, several authors (e.g. Rickard, 2000) stress the need to protect the crown from 'excessive winter wet'. This too could be studied experimentally by protecting or deliberately watering the crown during winter.

Francko (2003) in his recent book Palms Won't Grow Here and Other Myths provides extensive data and advice on winter protection of palms, and other potentially tender 'architectural' plants, in the northern United States where they would not normally be 
grown out of doors. Some of this advice may well be applicable to tree ferns planted outside in the UK. For example his 'three-year establishment rule', and his advocacy of particular mulches, screens, fertilizers, anti-desiccation leaf sprays, and fungicides in the crown.

\section{ACKNOWLEDGEMENT}

We thank Lynsey Muir, of the Photographic Department, for the pictures in the plates. We are very grateful to David Mitchell, Curator of the Indoor Department at RBGE, for his enthusiastic support of this work.

\section{REFERENCES}

FRANCKO, D.A. (2003). Palms Won't Grow Here and Other Myths. Portland, Timber Press.

LARGE, M.F. AND BRAGGINS, J.E. (2004) Tree Ferns. CSIRO Publishing, Melbourne, Australia.

RICKARD, M.H. (2000). The Plantfinder's Guide to Garden Ferns. Portland, Timber Press.

THE ROYAL HORTICULTURAL SOCIETY (1989). Gardeners' Encyclopaedia of Plants and Flowers, ed. C. Brickell. London, Dorling Kindersley.

WALTERS, S.M. et al. (1986). The European Garden Flora, Volume 1. Pteridophyta, Gymnospermae, Angiospermae - Monocotyledons (Part 1). Cambridge, Cambridge University Press.

WARDLAW, A.C. (2000). Practical Statistics for Experimental Biologists, 2nd Ed. Chichester, Wiley.

WARDLAW, A.C., GALLOWAY, L. \& ENSOLL, A. (2004). Tree fern apical temperatures at the Royal Botanic Garden Edinburgh. Sibbaldia: An occasional series of horticultural notes from the Royal Botanic Garden Edinburgh. 3, 17-26. 